\title{
Determination of Some Trace Elements in Breast Cancer Serum by Atomic Absorption Spectroscopy
}

\author{
Safaa Sabri Najim ${ }^{1}$ \\ ${ }^{1}$ Chemistry Department, College of Science, Misan University, Misan, Iraq \\ Correspondence: Safaa Sabri Najim, Chemistry Department, College of Science, Misan University, Misan, Iraq. Email: \\ safchem2000@yahoo.com
}

Received: September 14, 2016 Accepted: October 17, 2016 Online Published: November 21, 2016

doi:10.5539/ijc.v9n1p1

URL: http://dx.doi.org/10.5539/ijc.v9n1p1

\begin{abstract}
In the breast cancer significant differences occurs in the normal distribution of the trace elements, playing an important role in carcinogenic process. The aim of this study was to investigate the serum levels of some trace elements (Chromium, Cadmium, Manganese, Cobalt, Nickel, Selenium, Zinc, Iron, Copper and Magnesium) by using flame atomic absorption spectroscopy (FAAS). The present study included 150 females, the participates were divided into two main groups, control group which consisted of 75 apparently healthy females, 75patients with breast cancer group .The serum levels of Chromium $\left(t_{c a l} 2.9631, t_{t a b} 1.960\right)$, Cadmium $\left(t_{c a l} 2.0798, t_{\text {tab }} 1.960\right)$, Manganese $\left(t_{c a l} 18.5676, t_{t a b} 1.960\right)$, Selenium $\left(t_{c a l} 2.2759, t_{t a b} 1.960\right)$, Iron $\left(t_{c a l} 2.9296, t_{t a b} 1.960\right)$, Copper $\left(t_{c a l} 4.0869, t_{t a b} 1.960\right)$,Magnesium $\left(t_{c a l} 2.6648\right.$, $\left.t_{\text {tab }} 1.960\right)$, Cobalt $\left(t_{c a l} 3.8615, t_{\text {tab }} 1.960\right)$ and Zinc $\left(t_{c a l} 7.0160, t_{\text {tab }} 1.960\right)$ were statistically significant higher in the breast cancer patients group than the control group. Similarly, Nickel $\left(t_{c a l} 1.5988, t_{t a b} 1.960\right)$ levels showed significant lower level in breast cancer patients group. On the other hand, the higher levels of trace elements could lead to formation of free radicals or other reactive oxygen species. The evaluation of these trace elements in serum maybe used as helpful tool in diagnosis of the breast cancer.
\end{abstract}

Keywords: breast cancer, trace elements, serum, flame atomic absorption

\section{Introduction}

Almost 1.7 million new cases of breast cancer diagnosed in 2012, 12\% new of cancer cases and $25 \%$ of all cancers in women, causing death to women worldwide (Ferlay et al., 2012). The etiology of breast cancer is multi-factors which including, hormone, genetic and environmental can be affect the pathogenesis of the disease, but the exact factor are unknown (McPherson, Steel \& Dixon 2000) and (Russo, Fu, Yang \& Russo, 2000). Oxidative stress in the cells will predominate when the formation of reactive oxygen species (ROS) becomes too much, overpowering the normal antioxidant defense system, reduce the antioxidant system in addition to formation more free radicals (McKeown, 1999) and (Halliwell \& Cross, 1994). Many trace elements can activate or inhibit enzymes through rival with the other elements and metalloprotiens for binding sites or disturbing the cell membrane permeability, playing direct or indirect role on the carcinogenic routes (Huang, Sheu \& Lin, 1999). The increasing formation of free radicals may harm the tissue through the reaction with lipid cell membrane, proteins and nucleic acids (Halliwell, 2007). The cellular defense mechanisms (antioxidant mechanism) can control the free radicals species levels through, enzymatic (glutathione peroxidase, superoxide dismutase) and non-enzymatic compounds (vitamin E, vitamin C, glutathione and uric acid) (Badid et al., 2010).The oxidative damage to the biological molecules will create lipid peroxydation, mutagenesis, carcinogenesis (Kasapovic, Pejic,Todorovic, Stojiljkovic \& Pajovic, 2008). The air, drinking water and food are the natural resources of trace elements which the human can be exposure possibly modified (Bertini \& Cavallaro, 2008). The normal levels of the trace elements are essential to the human internal stability balance. The trace elements determination is important for their main role in the biochemical and physiological processes (Navoro \& Rohan, 2007).

The latest investigations discovered the relationship between the trace elements and cancer, some of them inducing the toxicity effect during the production of free radicals and acting as cofactors in oxidative destruction of the macromolecules and DNA (Leonard, Bower \& Shi, 2004).

The exact role of the serum trace elements levels in carcinogenesis, breast cancer, oxidative stress and different tumor markers are still shortage and pellicular (Navoro et al., 2007). The exact mechanism of tumor creation, high oxidative DNA damage after metal exposure is unclear. 
The variance of the trace elements levels in neoplastic breast tissues has been found through many investigations, on the other hand the metabolic and microenviromental factors which are responsible of the tumors creation are complex and not completely known (Silva \& Poletti, 2009). The aim of the present study was to investigate the association of the serum levels of some trace elements ,Chromium (Cr),Cadmium (Cd), Manganese (Mn),Cobalt (Co),Nickel $(\mathrm{Ni})$,Selenium $(\mathrm{Se})$, Zinc $(\mathrm{Zn})$,Iron $(\mathrm{Fe})$,Copper $(\mathrm{Cu})$ and Magnesium $(\mathrm{Mg})$ with breast cancer in order to add more knowledge to their rule in the patients ( Silva \& Poletti, 2009).

\section{Materials and Methods}

\subsection{Apparatus}

Aurora atomic absorption spectrophotometer model (AI-1200) was used with an air-acetylene burner (slot length $11 \mathrm{~cm}$ ). Instrument setting were: lamp current, $5-10 \mathrm{~mA}$, slit width, $0.2 \mathrm{~nm}$, air flow, $1.8 \mathrm{~L} / \mathrm{min}$, ignition flow $2.4 \mathrm{~L} / \mathrm{min}$ as shown in Table 1.These conditions were maintained constant throughout the measurements. The operating conditions adjusted according to the standard guideline of the manufacturer.

Table 1. Operating parameters of FAAS, wavelength, slit width, (HCL) current, range of calibration standardsand flame

\begin{tabular}{lllcll}
\hline Elements & $\begin{array}{l}\text { Wavelength } \\
(\mathrm{nm})\end{array}$ & Slit width (nm) & $\begin{array}{l}\text { HCLamp } \\
\text { current }(\mathrm{mA})\end{array}$ & $\begin{array}{l}\text { Range of Calibration } \\
\text { Standards }\end{array}$ & Flame \\
\hline $\mathrm{Cr}$ & 357.9 & 0.2 & 10 & $1-5 \mu \mathrm{g} / \mathrm{L}$ & Air/acetylene \\
$\mathrm{Cd}$ & 228.8 & 0.2 & 5 & $1-5 \mu \mathrm{g} / \mathrm{L}$ & Air/acetylene \\
$\mathrm{Mn}$ & 279.5 & 0.2 & 10 & $1-8 \mu \mathrm{g} / \mathrm{L}$ & Air/acetylene \\
$\mathrm{Co}$ & 240.7 & 0.2 & 7 & $1-8 \mu \mathrm{g} / \mathrm{L}$ & Air/acetylene \\
$\mathrm{Ni}$ & 232.0 & 0.2 & 1 & $1-10 \mu \mathrm{L} / \mathrm{L}$ & Air/acetylene \\
$\mathrm{Se}$ & 196.0 & 0.2 & 5 & $10-30 \mu \mathrm{L} / \mathrm{L}$ & Air/acetylene \\
$\mathrm{Zn}$ & 213.9 & 0.2 & 5 & $100-300 \mu \mathrm{g} / \mathrm{L}$ & Air/acetylene \\
$\mathrm{Fe}$ & 248.3 & 0.2 & 6 & $100-500 \mu \mathrm{g} / \mathrm{L}$ & Air/acetylene \\
$\mathrm{Cu}$ & 324.7 & 0.2 & 5 & $100-500 \mu \mathrm{g} / \mathrm{L}$ & Air/acetylene \\
$\mathrm{Mg}$ & 285.2 & 0.2 & $1-8 \mu \mathrm{g} / \mathrm{mL}$ & Air/acetylene \\
\hline
\end{tabular}

2.2 Reagents

A standard solution of each element was prepared immediately by serial dilution of $1000 \mathrm{mg} / \mathrm{L}$ stock solution (Scharlau Chemie) with deionized water prior to use.

\subsection{Preparation of Samples}

Seventy five female patients, with histopathological diagnosis of breast cancer, aged 26-62 years were selected from Al-sader public hospital in Misan- Iraq. Seventy five matched healthy women who attended routine health examination in the same hospital were selected from the same area with no history of any tumor or breast disease.

$10 \mathrm{ml}$ of venous blood without using anticoagulant samples were collected from patients and healthy volunteers in plain screw cap specimen bottles and then left for 30 min for retraction after, which centrifugation was carried out at 3000 $\mathrm{rpm}$ for $5 \mathrm{~min}$ and the supernatant serum was aspirated by using pasteur pipette into another plain bottle. The collected supernatant was then pooled and stored at $-20^{\circ} \mathrm{C}$ until the time of analysis. Serum samples was diluted with deionized water and homogenized before analysis.

\subsection{Statistical Analysis}

The data were subjected to statistical analysis using the student t-test for comparison of elements levels between patient and control groups. All the data were expressed as mean and standard deviation of the mean. The quantitative determination of the elements in samples was done by using calibration curves, linearity which obtained from diluted stock solution of each element $1000 \mathrm{mg} / \mathrm{L}$ as shown in Table 1 .The concentration of the analytes was obtained directly from the FAAS, through the linear regression's equations after the correction of the absorbance signal from the blank.

\section{Results and Discussion}

Ten trace elements as follows; chromium(Cr), cadmium (Cd), manganese (Mn)), cobalt(Co), nickel(Ni), selenium(Se), zinc $(\mathrm{Zn})$,iron $(\mathrm{Fe})$,copper $(\mathrm{Cu})$, and magnesium $(\mathrm{Mg})$ were identified and their concentrations were determined for each serum sample. The obtained concentration data was averaged separately for the control and breast cancer groups. The compares average concentrations along with the corresponding standard deviations for each element between 75 patients and 75 control groups are shown in Table 2.

The order of the mean trace elements concentrations in serum samples of breast cancer group is $\mathrm{Mg}>\mathrm{Fe}>\mathrm{Cu}>\mathrm{Zn}>\mathrm{Se}>$ $\mathrm{Ni}>\mathrm{Co}>\mathrm{Mn}>\mathrm{Cd}>\mathrm{Cr}$. Overall mean concentrations of $\mathrm{Mg}(20.51 \mu \mathrm{g} / \mathrm{mL}), \mathrm{Fe}(1671.4 \mu \mathrm{g} / \mathrm{L}), \mathrm{Cu}(1338.5 \mu \mathrm{g} / \mathrm{L}), \mathrm{Zn}$ $(920.75 \mu \mathrm{g} / \mathrm{L}), \mathrm{Se}(89.4 \mu \mathrm{g} / \mathrm{L}) \mathrm{Ni}(24.5 \mu \mathrm{g} / \mathrm{L}), \mathrm{Co}(20.3 \mu \mathrm{g} / \mathrm{L}), \mathrm{Mn}(15.3 \mu \mathrm{g} / \mathrm{L}), \mathrm{Cd}(14.5 \mu \mathrm{g} / \mathrm{L})$ and $\mathrm{Cr}(13.2 \mu \mathrm{g} / \mathrm{L})$ in breast cancer group, in contrast the order of the mean trace elements concentrations in serum samples of control group is $\mathrm{Mg}$ 
$>\mathrm{Fe}>\mathrm{Cu}>\mathrm{Zn}>\mathrm{Se}>\mathrm{Ni}>\mathrm{Mn}>\mathrm{Co}>\mathrm{Cd}>\mathrm{Cr}$, the corresponding mean levels of $\mathrm{Mg}(19.33 \mu \mathrm{g} / \mathrm{mL}), \mathrm{Fe}(1502.5 \mu \mathrm{g} / \mathrm{L}), \mathrm{Cu}$ $(1181.4 \mu \mathrm{g} / \mathrm{L}), \mathrm{Zn}(1175.4 \mu \mathrm{g} / \mathrm{L})$, Se $(96.8 \mu \mathrm{g} / \mathrm{L}) \mathrm{Ni}(27.1 \mu \mathrm{g} / \mathrm{L}), \mathrm{Mn}(25.8 \mu \mathrm{g} / \mathrm{L})$, Co $(14.9 \mu \mathrm{g} / \mathrm{L}), \mathrm{Cd}(12.9 \mu \mathrm{g} / \mathrm{L})$ and $\mathrm{Cr}$ $(11.3 \mu \mathrm{g} / \mathrm{L})$ in control group as shown in Figure 1, Figure 2.

To evaluate the differences between the mean trace element concentrations obtained in breast cancer and control groups, the mean trace elements concentration obtained for the two categories were subjected to a statistical student t-test analysis. At a 95\% confidence level, there were significant differences between the mean concentration of $\mathrm{Mg}$ $\left(t_{c a l} 2.6684, t_{t a b} 1.960\right), \quad \mathrm{Cu}\left(t_{c a l} 4.0869, t_{t a b} 1.960\right) \quad \mathrm{Mn}\left(t_{c a l} 18.5676, t_{t a b} 1.960\right), \quad \mathrm{Cd}\left(t_{c a l} 2.0798, t_{t a b} 1.960\right), \quad \mathrm{Cr}$ $\left(t_{c a l} 2.9631, t_{t a b} 1.960\right)$, Se $\left(t_{c a l} 2.2759, t_{t a b} 1.960\right)$, Fe $\left(t_{c a l} 2.9296, t_{t a b} 1.960\right)$, Co $\left(t_{c a l} 3.8615, t_{t a b} 1.960\right)$ and $\mathrm{Zn}\left(t_{c a l} 7.0160, t_{t a b} 1.960\right)$ obtained in breast cancer and control groups respectively, as shown in Table 2.

Table 2. Comparison of serum levels of 10trace elements between breast cancer patients and control groups, $(\mathrm{n}=75)$

\begin{tabular}{cccc}
\hline Elements & $\begin{array}{c}\text { Patient } \\
\text { Mean } \pm \text { SD }\end{array}$ & $\begin{array}{c}\text { Control } \\
\text { Mean } \pm \text { SD }\end{array}$ & t-value \\
\hline $\mathrm{Cr}(\mu \mathrm{g} / \mathrm{L})$ & $13.2 \pm 4.4$ & $11.3 \pm 3.4$ & 2.9631 \\
$\mathrm{Cd}(\mu \mathrm{g} / \mathrm{L})$ & $14.5 \pm 4.3$ & $12.9 \pm 5.1$ & 2.0798 \\
$\mathrm{Mn}(\mu \mathrm{g} / \mathrm{L})$ & $15.3 \pm 3.1$ & $25.8 \pm 3.8$ & 18.5676 \\
$\mathrm{Co}(\mu \mathrm{g} / \mathrm{L})$ & $20.3 \pm 10.3$ & $14.9 \pm 6.4$ & 3.8615 \\
$\mathrm{Ni}(\mu \mathrm{g} / \mathrm{L})$ & $24.5 \pm 9.3$ & $27.1 \pm 10.6$ & 1.5988 \\
$\mathrm{Se}(\mu \mathrm{g} / \mathrm{L})$ & $89.4 \pm 18$ & $96.8 \pm 21.7$ & 2.2759 \\
$\mathrm{Zn}(\mu \mathrm{g} / \mathrm{L})$ & $920.75 \pm 218.3$ & $1175.4 \pm 226.7$ & 7.0160 \\
$\mathrm{Cu}(\mu \mathrm{g} / \mathrm{L})$ & $1338.5 \pm 312.4$ & $1181.4 \pm 116.2$ & 4.0869 \\
$\mathrm{Fe}(\mu \mathrm{g} / \mathrm{L})$ & $1671.4 \pm 419.1$ & $1502.5 \pm 272.5$ & 2.9296 \\
$\mathrm{Mg}(\mu \mathrm{g} / \mathrm{mL})$ & $20.51 \pm 2.88$ & $19.33 \pm 2.54$ & 2.6648 \\
\hline
\end{tabular}

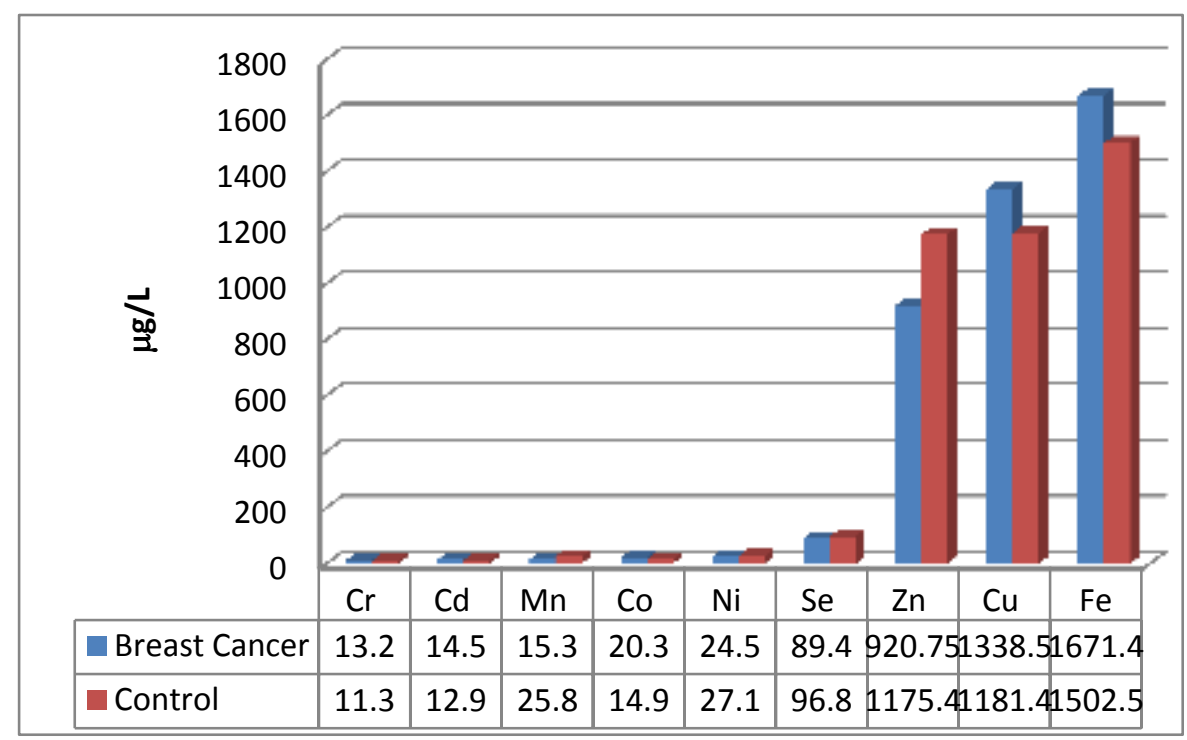

Figure 1. Mean concentrations of trace elements $(\mathrm{Cr}, \mathrm{Cd}, \mathrm{Mn}, \mathrm{Co}, \mathrm{Ni}, \mathrm{Se}, \mathrm{Zn}, \mathrm{Cu}$ and $\mathrm{Fe})$ in Breast Cancer and control groups $(\mathrm{n}=75)$ 


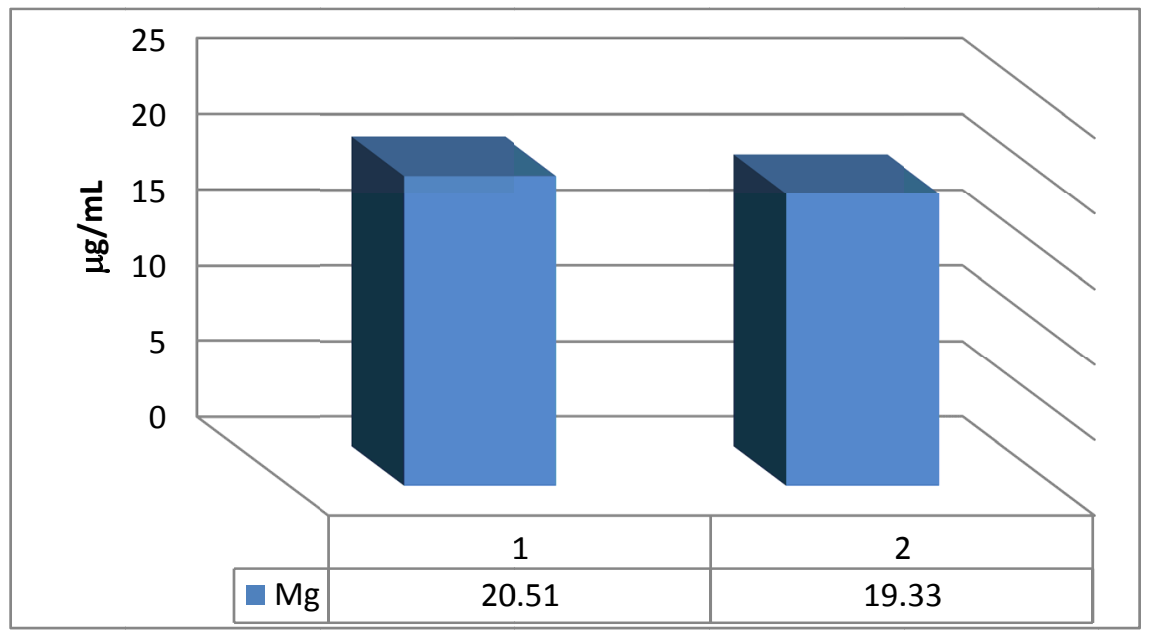

Figure 2. Mean Concentrations of $(\mathrm{Mg})$ in 1. Breast Cancer and 2. Control, groups $(\mathrm{n}=75)$

Too much trace elements formation can be toxic and carcinogenic. Metal ions involved in radical reactions, the formation of hydrogen peroxide and hydroxyl radicals from superoxide, activate the modification of lipoprotein. High levels of oxygen free radicals formation can be a reason for lipid peroxidation, mutagenesis, and carcinogenesis (Valko, Rhodes, Moncol, Izakovic \& Mazur, 2006). Oxidative damage can be stimulated by metal ions to the nucleus DNA and other cell components such as polyunsaturated fatty acid of phospholipids (Valko, Morris \& Cronin, 2005). Thus, the trace element levels are closely related to oxidant/antioxidant status in both pathological and physiological conditions. Copper ions can be support carcinogenesis through tumor series process (angiogenesis), during creating new capillaries from preexisting blood vessel (Park \&Floyd, 1992) and (Raju, Alesandrii, Zinche \& Gullino, 1982) in order to supply the needed nutritional requirements of growing tumors. The high levels of copper determination in breast cancer were mentioned by other authors (Huang, Sheu \& Lin, 1999), (Kuo, Chen, Wu, Chen \& Lee, 2002), (Zowczak, Iskra, Torlinski, \& Cofta, 2001), (Yucelet al., 1994) and (Siddiqui et al., 2006).Copper and Iron are necessary elements for humans, their concentrations above the physiological levels could initiate as well as support cancer by damaging DNA with free radicals. In the presence of redox-active transition elements Copper and Iron, reactive oxygen species (ROS) like hydrogen peroxide ( $\mathrm{H} 2 \mathrm{O} 2)$ and super oxide anion radical(O2-)are transformed into the highly reactive hydroxyl radical $(\mathrm{OH})$ via Fenton and Haber-Weiss type reactions (Sawyer \& Martell, 1987). The threats of cancer could be increased according to the alterations in immune functions (Zuin \& Principi, 1997). The shortage of zinc and selenium causes reduction in immunological competence (Baum, Miguez-Burbano, Campa \& Shor-Posner, 2000), (Rink \& Gabriel,2001), the hypotheses of zinc and selenium low levels could induce the threaten of cancer through decrease the antioxidant defense capability and reduce the immunological functions, supported by the low zinc and selenium concentrations noticed in breast cancer patients , mentioned in earlier studies(Huang et al.,1999) (Kuo et al.,2002) and (Magalovaet al., 1999) are in good agreement with the present observations. Magnesium is one of the physiologically efficient antioxidants, involves in more than 300antioxidant enzymatic reactions (Hasebe, 2005). Cadmium was significantly higher level in the breast cancer group than the control group. Cadmium affects cell proliferation, differentiation, apoptosis and signal transduction by enhancement of protein phosphorylation and activation of transcription and translation factors (Siewit, Gengler, Vegas, Puckett \& Louie, 2010). Cadmium prevents intercellular polypeptide to suppressing the formation of free radicals through the strong binding ability with them (Torreggiani, et al., 2009).

Significantly diminished concentrations of manganese and nickel observed in the sera of breast cancer patients might be a consequence of cancer. This can be understood in terms of the biochemical and histological differences between control and patient groups. The physiologic processes underlying tumor development can lead to an uptake of trace elements by the neoplastic breast cells because of the increased cellular and enzymatic activity.

\section{Conclusion}

The results obtained in this work suggest that there are correlation between the increasing serum levels of certain trace elements $(\mathrm{Cr}, \mathrm{Cd}, \mathrm{Cu}, \mathrm{Fe}, \mathrm{Co}$ and $\mathrm{Mg}$ ) and decrease in the others $(\mathrm{Mn}, \mathrm{Ni}, \mathrm{Se}, \mathrm{Zn}$ and $\mathrm{Zn})$ consequent in the serum breast cancer patients. There are significant differences at a 95\% confidence level of the means levels $(\mathrm{Cr}, \mathrm{Cd}, \mathrm{Mn}, \mathrm{Co}$, $\mathrm{Zn}, \mathrm{Se}, \mathrm{Fe}, \mathrm{Mg}$ and $\mathrm{Cu}$ ). It seems that the increased levels of trace elements could lead to formation of free radicals or other reactive oxygen species inducing oxidative stress. It is recommended to use trace elements as biomarkers for breast cancer. The serum profile of these trace elements may be helpful in predicting prognosis of breast cancer. 
This study warrant further investigations on larger sample size, more other trace elements and multiple serum samples.

\section{Acknowledgements}

This research received no specific grant from any funding agency, commercial or not for profit sector. The author would like to thank Al-Sader public hospital in Misan for their cooperation to collect the samples.

\section{References}

Badid, N., Ahmed, F. Z., Merzouk, H., Belbraouet, S., Mokhtari, N., \& Merzouk, S. A. (2010). Oxidant/Antioxidant Status, Lipids and Hormonal Profile in Overweight Women with Breast Cancer. Pathology and Oncology Research, 16, 159-167. https:/doi.org/10.1007/s12253-009-9199-0

Baum, M. K., Miguez-Burbano, M. J., Campa, A., \& Shor-Posner, G. (2000). Selenium and Interleukins in Persons Infected with Human Immunodeficiency Virus Type 1, J. Infect. Dis., 182, S69-S73. https:/doi.org/10.1086/315911

Bertini, I., \& Cavallaro, G. (2008). Metals in the "Omics" World: Copper Homeostasis and Cytochrome Oxidase Assembly in a New Light. JBIC Journal of Biological Inorganic Chemistry, 13, 3-14. https:/doi.org/10.1007/s00775-007-0316-9

Ferlay, J., Soerjomataram, I., Ervik, M., Dikshit, R., Eser, S., \& Mathers, C. (2012). Cancer incidence and mortality worldwide: IARC Cancer Base No., 11. GLOBOCAN; 1.

Halliwell, B. (2007). Oxidative Stress and Cancer, Biochemical Journal, 401(111). https:/doi.org/10.1042/BJ20061131

Halliwell, B., \& Cross, C. E. (1994). Oxygen-derived species: their relation to human disease and environmental stress. Environ, Health, Perspect., 102, 5-12. PMID: 7705305. https:/doi.org/10.1289/ehp.94102s105

Hasebe, N. (2005). Oxidative stress and magnesium. Clin Calcium., 15, 194-202. PMID: 15692157

Huang, Y. L., Sheu, J. Y., \& Lin, T. H. (1999). Association between oxidative stress and changes of trace elements in patients with breast cancer. Clin. Biochem., 32(2), 131-136. PMID: 10211630. https:/doi.org/10.1016/S0009-9120(98)00096-4

Huang, Y. L., Sheu, J. Y., \& Lin, T. H. (1999). Association between oxidative stress and changes of trace elements in patients with breast cancer, Clin. Biochem., 32, 131-136. https:/doi.org/10.1016/S0009-9120(98)00096-4

Kasapovic, J., Pejic, S., Todorovic, A., Stojiljkovic, V., \& Pajovic, S. B. (2008). Antioxidant Status and Lipid Peroxidation in the Blood of Breast Cancer Patients of Different Ages. Cell Biochemistry \& Function, 26, 723-730. https:/doi.org/10.1002/cbf.1499

Kuo, H. W., Chen, S. F., Wu, C. C., Chen, D. R., \& Lee, J. H. (2002). Serum and tissue trace elements in patients with breast cancer in Taiwan. Biol. Trace Elem. Res., 89, 1-11. https:/doi.org/10.1385/BTER:89:1:1

Leonard, S. S., Bower, J. J., \& Shi, X. (2004). Metal-Induced Toxicity, Carcinogenesis, Mechanisms and Cellular Responses. Molecular and Cellular Biochemistry, 255, 3-10. PMID: 14971640. https:/doi.org/10.1023/B:MCBI.0000007255.72746.a6

Magalova, T., Bella, V., Brtkova, A., Beoo, I., Kudlaekova, M., \& Volkovova, K. (1999). Copper, zinc and superoxide dismutase in precancerous, benign diseases and gastric, colorectal and breast cancer. Neoplasma, 46, 100-104.

McKeown, N. (1999). Antioxidants and breast cancer. Nutr. Rev., 57, 321-324. PMID: 10575909.

McPherson, K., Steel, C. M., \& Dixon, J. M. (2000). Breast cancer epidemiology, risk factors, genetics. Br. Med. J., 321, 624-628. PMID: 10977847. https:/doi.org/10.1136/bmj.321.7261.624

Navoro, S. S., \& Rohan, T. E. (2007). Trace Elements and Cancer Risk: A Review of the Epidemiologic Evidence. Cancer Causes Control, 18, 7-27. https:/doi.org/10.1007/s10552-006-0057-z

Park, J. W., \& Floyd, R. A. (1992). Lipid peroxidation products mediate the formation of 8-hydroxydeoxyguanosine in DNA. Free Radic. Biol. Med., 12, 245-250. https:/doi.org/10.1016/0891-5849(92)90111-S

Raju, K. S., Alesandrii, G., Zinche, M., \& Gullino, P. M. (1982). Ceruloplasmin, copper ions, and angiogenesis $J$. Natl. Cancer Inst., 69, 1183-1188. PMID: 6182332.

Rink, L., \& Gabriel, P. (2001). Extracellular and immunological actions of zinc, Biometals, 14, 367-383. PMID: 11831466. https:/doi.org/10.1023/A:1012986225203

Russo, J., Fu, H. Y., Yang, X., \& Russo, I. H. (2000). Developmental, cellular, and molecular basis of human breast cancer. J. Natl. Cancer Inst. Monogr., 27, 17-37. PMID: 10963618. https:/doi.org/10.1093/oxfordjournals.jncimonographs.a024241 
Sawyer, D. T., \& Martell, A. E. (1987). Oxygen complexes and oxygen activation by transition metals. Plenum Press, New York, 131-148.

Siddiqui, M. K., Jyoti, S. S., Mehrotra, P. K., Singh, K., \& Sarangi, R. (2006). Comparison of some trace elements concentration in blood, tumor free breast and tumor tissues of women with benign and malignant breast lesions: an Indian study. Environ In., 32, 630-637. https:/doi.org/10.1016/j.envint.2006.02.002

Siewit, C. L., Gengler, B., Vegas, E., Puckett, R., \& Louie, M. C. (2010). Cadmium Promotes Breast Cancer Cell Proliferation by Potentiating the Interaction between ER Alpha and c-Jun. Molecular Endocrinology, 24, 981-992. https:/doi.org/10.1210/me.2009-0410

Silva, A., \& Poletti, M. E. (2009). Determination of $\mathrm{Ca}, \mathrm{Fe}, \mathrm{Cu}$ and $\mathrm{Zn}$ and Their Correlations in Breast Cancer and Normal Adjacent Tissues. X-Ray Spectrometry, 38, 103-111. https:/doi.org/10.1002/xrs.1126

Torreggiani, A., Domènech, J., Orihuela, R., Ferreri, C., Atrian, S., Capdevila, M., \& Chatgilialoglu, C. (2009). Zinc and cadmium complexes of a plant metallothionein under radical stress: desulfurisation reactions associated with the formation of trans - lipids in model membranes. Chem. Eurq. J., 15, 6015-660. https:/doi.org/10.1002/chem.200802533

Valko, M., Morris, H., \& Cronin, M. T. (2005). Metals, toxicity and oxidative stress. Curr. Med. Chem., 12, 1161-1208. https:/doi.org/10.2174/0929867053764635

Valko, M., Rhodes, C. J., Moncol, J., Izakovic, M., \& Mazur, M. (2006). Free radicals, metals and antioxidants in oxidative stress-induced cancer. Chem. Biol. Interac., 160, 1-40. https:/doi.org/10.1016/j.cbi.2005.12.009

Yucel, I., Arpaci, F., Ozet, A., Doner, B., Karayilanoglu, T., Sayar, A., \& Berk, O. (1994). Serum copper and zinc levels and copper/zinc ratio in patients with breast cancer, Biol. Trace. Elem. Res., 40, 31-38. https:/doi.org/10.1007/BF02916818

Zowczak, M., Iskra, M., \& Torlinski, L., \& Cofta, S. (2001). Analysis of serum copper and zinc concentrations in cancer patients. Biol Trace Elem Res., 82, 1-8. https:/doi.org/10.1385/BTER:82:1-3:001

Zuin, G., \& Principi. N. (1997). Trace elements and vitamins in immunomodulation in infancy and childhood. Eur. J. Cancer Prev., 6, S69-S77. https:/doi.org/10.1097/00008469-199703001-00012

\section{Copyrights}

Copyright for this article is retained by the author(s), with first publication rights granted to the journal.

This is an open-access article distributed under the terms and conditions of the Creative Commons Attribution license (http://creativecommons.org/licenses/by/4.0/). 